\title{
Projeção da Imagem Partidária nas Estratégias de Campanha na Televisão: Uma Análise do HGPE 2002
}

Marcia Ribeiro Dias

\section{INTRODUÇÃO}

D a condição de atores centrais da dinâmica eleitoral nos sistemas democráticos contemporâneos, os partidos políticos tiveram nos últimos anos sua morte anunciada. O declínio evidente e irreversível de seu papel como intermediários privilegiados das relações entre Estado e sociedade vem sendo constatado em inúmeros estudos, especialmente na área de comunicação e política. E não é de se surpreender, pois o próprio campo de estudos da comunicação e política nasceu e se desenvolveu à sombra de um intenso processo de profissionalização das campanhas eleitorais que ocorreu, simultaneamente, à decadência de algumas funções clássicas dos partidos políticos, especialmente na formação da opinião pública e na definição do voto pelos eleitores.

A associação entre esses dois fenômenos se deu de tal forma que se estabeleceu entre eles uma relação causal que, em outra parte, denominamos de "argumento da substituição": a ascensão e proeminência crescente dos meios de comunicação no jogo eleitoral teriam determinado a decadência dos partidos na dinâmica política recente, nos termos de uma substituição dos segundos pelos primeiros (Albuquerque e Dias, 2002).

DADOS - Revista de Ciências Sociais, Rio de Janeiro, Vol. 48, n-1, 2005, pp. 149 a 187. 
Para fins de empreender um diagnóstico geral do problema, a associação entre esses dois fenômenos é perfeitamente plausível. O espaço deixado pelos partidos na arena representativa, que podemos relacionar a uma crise geral da representação política nas democracias contemporâneas, foi ocupado pelos veículos de comunicação com vantagem, tanto por sua capacidade difusora de informação quanto pela eficiência de seus meios. O rádio, a televisão e, mais recentemente, a internet reduziram significativamente os custos da informação política, na medida em que eliminaram a necessidade de participação e trouxeram para o ambiente doméstico a informação necessária tanto à formação da opinião quanto à decisão do voto. O que se questiona neste artigo é a ordem dos fatores dessa equação: o declínio dos partidos políticos não é uma função da ascensão de novas tecnologias da informação na contemporaneidade, mas fruto de um processo histórico cujas raízes se encontram nos termos do contrato representativo que legitima a forma do moderno governo democrático.

O objetivo deste artigo é recuperar a discussão teórica acerca do modelo representativo da democracia a fim de fundamentar a explicação da crise atravessada pelos partidos na atual dinâmica política, enfocando, especialmente, as campanhas eleitorais recentes. Uma vez dissociada do paradigma do avanço de novas tecnologias de informação e comunicação, a crise dos partidos poderá deixar de ser encarada como um declínio irreversível dos mesmos e passar a ser entendida como uma reconfiguração de seu papel na arena democrática contemporânea. Essa reconfiguração passa, necessariamente, pela incorporação dessas novas tecnologias à sua comunicação com o eleitor, não deixando esta de ser uma variável importante na explicação da dinâmica política atual.

Os dados empíricos aqui trabalhados apontam para a sobrevivência e o sucesso de estratégias coletivistas que vêm sendo utilizadas pelos partidos políticos como instrumentos para a persuasão da vontade do eleitor em prol de seu projeto político governamental. O que se quer demonstrar é que as circunstâncias específicas do modelo brasileiro de propaganda política, que só admite o acesso gratuito dos partidos à campanha eleitoral na televisão, podem se tornar um valioso "campo de provas" de uma nova dimensão na identificação partidária pelos eleitores e da reformulação das funções dos partidos na arena política representativa. 


\section{A CRISE DA REPRESENTAÇÃO POLÍTICA E O DECLÍNIO DOS PARTIDOS NAS DEMOCRACIAS CONTEMPORÂNEAS}

A fonte de legitimidade do sistema democrático contemporâneo encontra-se no mecanismo de escolha dos governantes pelos governados. Os cidadãos delegam sua soberania no ato eleitoral e, por meio do voto, autorizam a ação governamental, tornando-se sujeitos a ela. O modelo representativo de governo originado desse sistema é legitimado pela capacidade que o representante tem de traduzir a vontade popular sob a forma de políticas públicas, constituindo um modelo de democracia indireta. É importante, entretanto, marcar a distinção entre as noções de democracia e governo representativo que, não sendo sinônimos, operam funções distintas dentro do sistema político.

O ideário democrático tem como pilar central de sustentação a identificação da fonte do poder político diretamente no povo. Isto implica dizer que, para ser considerado democrático, um governo tem que contar com a concordância do povo, tanto no que diz respeito a quem governa quanto a como governa. A legitimidade de um governo democrático, portanto, está no grau de identificação entre os cidadãos e o Estado, no sentido de que os primeiros se reconheçam nas ações do segundo.

O governo representativo tem como atributo fundamental a separação entre governantes e governados por via do mecanismo da representação política, que os transforma em entidades políticas autônomas, porém interdependentes. Tanto os governados buscam influenciar o curso da ação que é conduzida pelos governantes quanto esta ação produz impacto sobre os governados, gerando maior ou menor grau de satisfação com o funcionamento do mecanismo representativo. Tal mecanismo é operado por agentes intermediários, entre os quais os partidos políticos, que detêm um status privilegiado conferido pelo monopólio da representação política. É este monopólio que condiciona qualquer candidatura a cargo político eletivo à filiação a um partido político.

Se compararmos o governo representativo à formulação original da democracia, este não é mais um governo que se exerce pelo povo, mas por uma elite política selecionada para traduzir a vontade popular e a partir dela governar. A tradução dessa vontade dependerá da sensibilidade dos governantes em perceber as demandas dos cidadãos, da 
confluência dos interesses no interior das Assembléias Legislativas e das respostas que são fornecidas sob a forma de políticas públicas. No contexto dessa tradução, a eficácia dos partidos políticos, como agentes intermediários centrais, é determinante em boa parte de seus resultados e do nível de satisfação que suscita entre os governados. Nesse sentido, o questionamento do mecanismo representativo surge quando o povo se sente insatisfeito com a tradução de sua vontade pelos representantes, ou seja, quando esta se torna imperfeita ou francamente distanciada do que o povo entende como sendo realmente a sua vontade.

A conjunção entre as idéias de democracia e representação, intencionada pela controversa expressão "democracia representativa", depende da satisfação do critério democrático pelos governos representativos, ou seja, da capacidade de estes governos fornecerem respostas adequadas às demandas dos cidadãos e do controle destes últimos sobre os referidos governos. O debate acerca da "crise" da democracia representativa, muito freqüente na literatura acadêmica a partir dos anos 70, tem como um de seus principais pilares o questionamento do papel dos representantes junto ao seu eleitorado. Tem sido apontado o fato de os governos estarem se afastando progressivamente dos anseios da sociedade, de não estarem sendo responsivos à vontade popular. $\mathrm{O}$ argumento comum que tem embasado as distintas perspectivas sobre a crise da democracia representativa, especialmente nos países da Europa Ocidental, é o aumento progressivo das demandas dos cidadãos em contraposição ao declínio da capacidade do Estado em implementar políticas, principalmente em função da redução no ritmo do crescimento econômico daqueles países (Klingemann e Fucks, 1995).

O debate em torno da crise de legitimidade do modelo de governo representativo é demasiado extenso, já tendo atravessado três décadas, para ter aqui contempladas suas várias facetas ${ }^{1}$. $O$ fato é que questionados ou não, mais ou menos marcados por uma transformação no relacionamento entre os cidadãos e o Estado, os governos representativos continuam em funcionamento e não sofreram nenhuma mudança estrutural significativa em seus componentes característicos, como os sistemas partidários. Estes continuam sendo os intermediários privilegiados da relação entre governantes e governados. Entretanto, não há como ignorar as transformações processuais nessa complexa relação de intermediação política, que marcam o contexto da contro- 
vérsia acerca do declínio dos partidos políticos nas democracias contemporâneas.

\section{O "Declínio" dos Partidos Políticos e a "Profissionalização" das Campanhas Eleitorais}

Os partidos políticos surgiram na cena política ocidental como organizações voltadas para a viabilização de projetos políticos por intermédio da conquista de cargos em disputas eleitorais. Os propósitos dos partidos políticos variam em função da ideologia política que orienta a ação de seus membros. À medida que um partido amplia o número de cargos por ele ocupados na esfera estatal, seu prestígio e poder políticos também se acentuam, assim como sua capacidade de definir o curso das políticas públicas para a sociedade.

Ao longo do século XX, especialmente em sua primeira metade, os partidos políticos enraizaram-se nas sociedades ocidentais, consolidando-se como os principais atores políticos em sistemas democráticos. O reflexo desse status diferenciado dos partidos com relação às demais instituições da sociedade civil pôde ser verificado em sua capacidade de organizar as demandas sociais, canalizar as preferências do eleitorado, engendrar soluções para os problemas cruciais da organização da vida em sociedade e formar a opinião política.

Os cidadãos, por sua vez, formam e identificam suas preferências nos projetos políticos incorporados pelos partidos, outorgando aos seus representantes suporte eleitoral para agir em seu nome. O comportamento eleitoral funciona, portanto, como um termômetro que mede a satisfação dos eleitores com relação à ação do(s) partido(s) governante(s) (voto retrospectivo) ou da busca por novas soluções para os problemas coletivos (voto prospectivo). Assim, o mecanismo institucional que regula a satisfação com governos representativos é o eixo governo-oposição: os partidos que satisfazem as expectativas da maioria do eleitorado ocupam posições no governo, enquanto os partidos minoritários nas preferências eleitorais assumirão funções oposicionistas, especialmente no Parlamento ou Congresso. Esse mecanismo é tanto mais efetivo na medida em que os cidadãos identificam em um partido político a capacidade de representar seus interesses e vislumbram a chance de que este chegue ao governo algum dia (idem).

Um amplo processo de modernização das estruturas sociais - marcado por importantes transformações sociais, econômicas e tecnológi- 
cas - ocorreu, principalmente, a partir de meados do século XX, alterando os mecanismos de identificação entre cidadãos e partidos políticos. Uma das principais conseqüências desse processo foi a reestruturação do sistema de classes, caracterizada pela ampliação das classes médias em função da progressiva conquista de condições de bem-estar social. Tal ampliação tornou indefinidas as fronteiras entre as diferentes classes sociais, enfraquecendo a ligação - característica do início do século - entre partidos e classes. Nesse tipo de vinculação, a identificação partidária forjava-se na defesa dos interesses e a partir da visão de mundo de uma determinada classe social. A diluição das identidades de classe trouxe também o enfraquecimento dos laços de solidariedade social, configurando percepções cada vez mais individualistas sobre a esfera pública.

Dessas transformações na estrutura social resultou a atenuação das posturas ideológicas nos partidos políticos. Não sendo mais possível precisar as identidades sociais em função de seu caráter progressivamente hegemônico, os programas políticos dos partidos tornaram-se mais semelhantes. O eleitorado das principais democracias do mundo ocidental observou uma convergência para o centro político, passando a rejeitar projetos políticos extremados. Nesse sentido, é possível dizer que a imprecisão ideológica do eleitorado acarretou a imprecisão ideológica dos partidos políticos.

Indiferenciados no plano ideológico, os partidos não puderam mais contar com a lealdade incondicional de um eleitorado relativamente constante; esse eleitorado passou a obedecer a um tipo de orientação predominantemente instrumental, ou seja, pautada por critérios utilitários e individualistas. Como os partidos começaram a adotar posturas e propostas políticas muito semelhantes, os eleitores voltaram-se para critérios de diferenciação mais personalistas, relacionados às características pessoais do candidato ou frutos de questões da pauta pública selecionadas pelos candidatos em seu programa eleitoral. A conquista da maioria desse eleitorado, condição para o exercício governamental, passou a ser uma luta permanente dos partidos políticos em demonstrar boa performance e eficiência (Streeck, 1987 apud idem $)^{2}$.

A década de 90 foi palco de profundas transformações nos estilos e práticas das campanhas eleitorais, impulsionadas pelo modelo norte-americano surgido ainda na década de 80 . A natureza dessas mu- 
danças revela a modernização dos métodos e técnicas utilizados em campanhas eleitorais, em um fenômeno marcado principalmente pela centralidade da televisão na comunicação política. No bojo dessas transformações, encontra-se o processo de personalização das campanhas eleitorais, caracterizado pela substituição do modelo partidário pelo midiático de competição entre personalidades (Plasser, $2001)^{3}$.

Nos modelos de campanhas profissionais, as disputas eleitorais são comparadas aos mecanismos de funcionamento do mercado: os partidos são empresas que por intermédio de seus funcionários, os candidatos, tentam vender seus produtos, os projetos de políticas públicas, aos consumidores, os eleitores, que usam o seu voto como moeda de troca ${ }^{4}$. Estes últimos não apresentam nenhuma fidelidade partidária e se caracterizam justamente pela volatilidade de suas preferências, podendo ser persuadidos por profissionais do marketing político.

A profissionalização das campanhas tem como marca fundamental a evolução nas tecnologias da comunicação que, segundo se argumenta, teria promovido a substituição da intermediação direta dos partidos pelo estilo de comunicação indireta - via rádio, televisão, telefone, internet e $e$-mail -, pelo uso de pesquisas de opinião e grupos focais, e pela introdução de profissionais especializados em técnica de formulação e condução de campanhas comerciais, agora aplicadas à propaganda política (Gibson e Römmele, 2001; ver, ainda, Plasser, 2001; Negrine e Lilleker, 2002; Römmele, 2003).

A associação entre o estilo profissional de campanha e o declínio dos partidos políticos na dinâmica eleitoral é estabelecida, imediatamente, em quase todos os estudos que vêm sendo produzidos sobre comunicação política, como evidenciado na passagem a seguir:

"[...] o declínio da relevância dos partidos em campanhas eleitorais é um fenômeno universal causado por uma transformação no ambiente midiático, por uma redução no percentual de identificação partidária no eleitorado e pelo aumento na afluência de consultores políticos externos às operações gerenciais e estratégicas, antes conduzidas pelos próprios partidos, mas hoje em dia mais e mais delegadas a profissionais de campanha externos altamente especializados [...]" ( Plasser, 2001:48-49). 
O argumento que aqui desenvolvo é que não existe uma relação causal entre a profissionalização das campanhas e o "declínio" dos partidos políticos, mas que ambos são fenômenos independentes derivados de um mesmo processo: a modernização das estruturas sociais, o aumento das demandas feitas ao Estado e o declínio da capacidade econômica deste último. A crise das democracias representativas é, antes de tudo, uma crise de legitimidade dos agentes intermediários entre os cidadãos e o Estado, causada pela incapacidade desses agentes de fornecerem respostas adequadas aos novos dilemas apresentados à dinâmica política representativa. A ascensão dos meios de comunicação nos processos eleitorais é fruto exclusivamente da modernização tecnológica, à qual os partidos políticos podem se ajustar com maior ou menor eficiência. Ou seja, o uso que os partidos fazem desses novos mecanismos de comunicação pode ser determinante da reconfiguração de seu papel na arena política.

O que pretendo neste artigo é recusar a hipótese da substituição mediante a investigação das recentes estratégias utilizadas pelos partidos na construção de sua imagem, via televisão, junto ao eleitorado. Se for verdade que os modernos meios de comunicação substituíram os partidos políticos em suas funções de intermediação entre os cidadãos e o Estado, teremos que constatar a redução da identificação partidária pelos eleitores e o declínio das estratégias comunicativas em campanhas eleitorais que visem construir uma imagem coerente dos partidos junto ao eleitorado.

Na segunda parte deste artigo, discuto questões relativas à identificação partidária no Brasil, perspectivas históricas e tendências recentes. Em seguida, irei abordar algumas características fundamentais do modelo de propaganda política na televisão que opera neste país; também analisarei os dados do Horário Gratuito de Propaganda Eleitoral - HGPE de 2002, visando construir uma tipologia de estratégias de campanha que permita fazer um diagnóstico da imagem construída por alguns partidos brasileiros, tanto no plano individual quanto sistêmico. Não será possível apontar tendências de declínio ou ascensão no uso de estratégias comunicativas coletivistas (ênfase partidária), pois apenas um ano eleitoral será analisado. O trabalho comparativo, que permita verificar a evolução na construção da imagem partidária no Brasil, é tarefa a ser assumida em trabalhos futuros. 


\section{IDENTIFICAÇÃO PARTIDÁRIA E PROPAGANDA POLÍTICA NO BRASIL}

A história política brasileira revela uma frágil associação entre os partidos políticos e seus eleitores. Sua dinâmica política sempre foi marcada por um forte conteúdo personalista, traduzido pela preferência explícita dos eleitores por um tipo de voto orientado pelos atributos individuais dos candidatos em disputa. Um dos sintomas dessa tendência no comportamento eleitoral brasileiro pode ser vislumbrado no fato de as taxas de votos de legenda serem sempre inferiores à incidência de votos nominais. Outra evidência desse fenômeno pode ser encontrada em pesquisas de opinião que confirmam a preferência dos eleitores brasileiros por critérios de escolha eleitoral relacionados ao perfil do candidato em detrimento de uma escolha partidária ${ }^{5}$.

Desde a nacionalização dos partidos políticos, operada no final da primeira fase da Era Vargas (1945), nunca pôde ser percebida uma significativa identificação partidária entre os eleitores no Brasil. Foi notável, entretanto, o fortalecimento do sistema de partidos que vigorou entre 1946 e 1964, culminando na consolidação de lealdades partidárias e de um padrão de identificação por parte dos eleitores ao final desse período (Lavareda, 1999). O golpe militar de 64 interrompeu esse processo, extinguindo os antigos partidos e instaurando um sistema bipartidário compulsório (Arena* e MDB), o que contribuiu para o distanciamento e a descrença dos eleitores do sistema representativo que então vigorava.

É possível dizer que a volta do multipartidarismo não apenas não produziu impacto imediato na politização do eleitor como foi acompanhada de um declínio na identificação partidária ${ }^{6}$. Vale lembrar que boa parte desse novo sistema multipartidário foi composta pelo desmembramento da Arena e do MDB, e que seus eleitores não transferiram sua preferência para suas novas legendas. O declínio na preferência pelo PDS e pelo PMDB foi vertiginoso, especialmente no caso do primeiro. Ao contrário, o partido que mais cresceu inicialmente foi o herdeiro político do antigo PTB, resgatado pela ala dos "trabalhistas históricos", liderada por Leonel Brizola, por via da fundação do PDT. Em seguida, o partido que começou a crescer progressivamente na

\footnotetext{
* Ver Glossário no final deste artigo.
} 
preferência do eleitor brasileiro foi o PT, legenda completamente nova, nascida dos movimentos sociais do final da década de 70 .

Em 1989, ano da primeira eleição direta para presidente da República desde 1960, 62\% dos brasileiros declaravam não ter identificação com nenhum partido. Dos que declaravam alguma preferência partidária, o único percentual significativo (12\%) foi atribuído ao PMDB, enquanto PT, PDT, PDS e PFL observavam percentuais entre $6 \%$ e $4 \%$ (Instituto Datafolha).

O pleito eleitoral daquele ano também foi emblemático do alto grau de personalismo e da reduzida importância dos partidos no cenário político nacional. O candidato vitorioso, Fernando Collor de Mello, empreendeu uma campanha calcada fundamentalmente na valorização de atributos individuais e estava associado a uma legenda partidária irrelevante e desconhecida, o PRN. A imagem deste partido foi construída em associação tão íntima com a imagem do novo presidente que a ruína política deste levou ao desaparecimento daquele. Outro dado excepcional das eleições de 1989 foi o desempenho do PMDB, partido que, como vimos, angariava o maior percentual de preferência por parte dos eleitores: seu candidato, Ulysses Guimarães, ficou em sétimo lugar na disputa, com apenas 4,7\% dos votos nacionais (Nicolau, 1998).

Nesse sentido, 1989 foi um ano emblemático da fragilidade dos partidos políticos na dinâmica eleitoral brasileira. Desde então, algumas alterações sensíveis puderam ser observadas no quadro de preferências partidárias nacionais. O Gráfico 1 revela a evolução da identificação dos eleitores com os seis maiores partidos brasileiros entre 1989 e 2001.

Pelo Gráfico 1 é possível observar alguns padrões evolutivos na preferência do eleitores brasileiros pelos partidos políticos. O PMDB e o PFL apresentaram uma relativa constância: em termos globais mantiveram os mesmos índices de identificação entre os eleitores, embora se constate momentos de ascensão nestes índices. Entre os anos de 1991 e 1993, a preferência pelo PMDB teve uma ligeira elevação, chegando a 19\%, passando por um momento de declínio entre 1994 e 1999 , e se estabilizando nos mesmos $12 \%$ iniciais. Entre os anos de 1995 e 1997 foi o PFL que elevou sua taxa de identificação partidária, 
Gráfico 1

Identificação Partidária no Brasil (1989-2001)

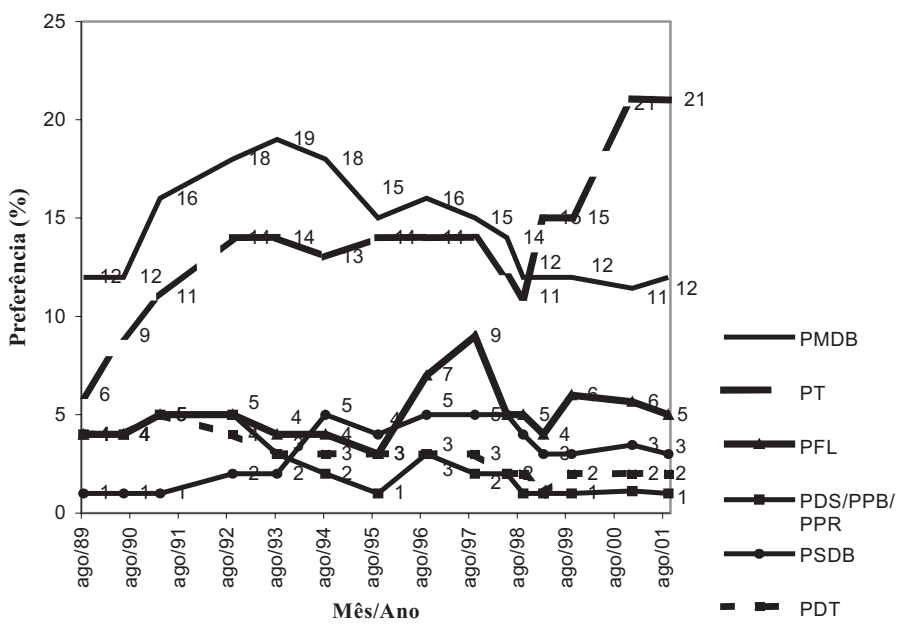

Fonte: Instituto Datafolha.

chegando a $9 \%$ em 1997. Observa-se, entretanto, um declínio a partir de então, voltando à estabilidade entre os anos de 1999 e 2001 (5\%).

Outros dois partidos vivenciaram uma tendência de queda ao longo de todo o período. Tanto o PPB (atual PP) quanto o PDT partiram do índice de $4 \%$ na preferência dos brasileiros, em 1989, chegando o primeiro a $1 \%$ e o segundo a $2 \%$ em 2001. Sintomático da crise do PP, originariamente Arena, foram as mudanças sucessivas em sua legenda de 1989 até hoje: de PDS, sua primeira legenda após o fim do bipartidarismo, passou a PPR, em seguida para PPB, chegando ao atual PP. Já o PDT seguiu o declínio na popularidade de sua principal liderança, o ex-governador do Rio de Janeiro Leonel Brizola. Mas, sobretudo, o declínio do PDT está associado à ascensão vigorosa do PT na preferência dos brasileiros, em virtude de estes dois partidos disputarem, inicialmente, uma mesma fatia do eleitorado ${ }^{7}$.

O PSDB e o PT gozaram um movimento de ascensão, mais ou menos regular, ao longo do período, em proporções muito diferentes, vale ressaltar. O PSDB teve sua taxa de identificação partidária incrementada a partir de 1994 com o Plano Real e a vitória de Fernando Henrique Cardoso nas eleições presidenciais daquele ano, mantendo-se na faixa dos 5\% até 1998. Durante o segundo mandato de FHC, que com- 
Gráfico 2

Identificação Partidária no Brasil (1989-2001)

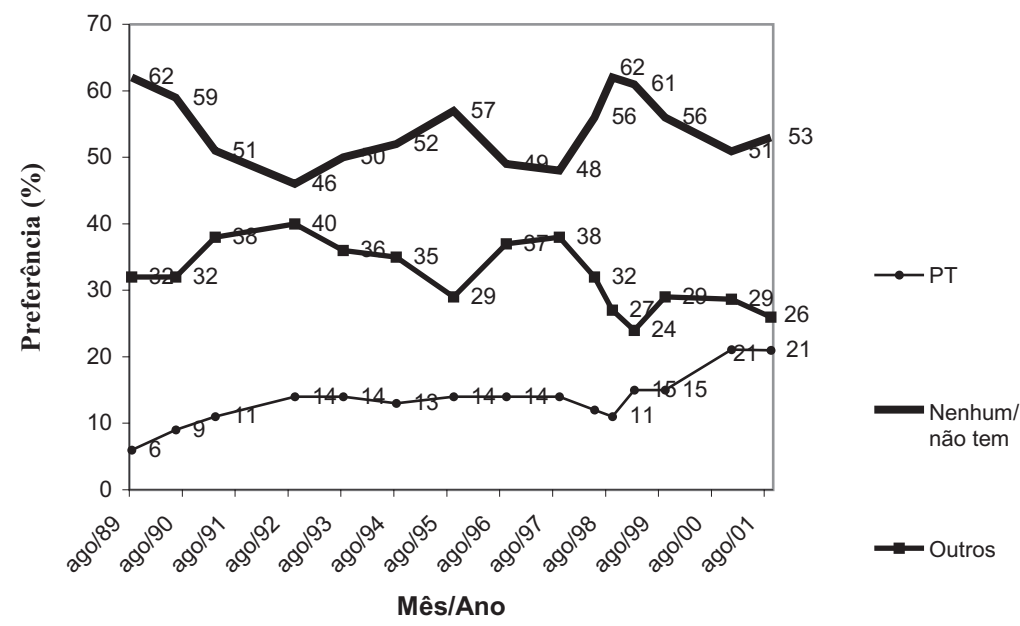

Fonte: Instituto Datafolha.

preendeu os anos 1999 a 2002, ocorreu um declínio da popularidade do PSDB, que chegou a 2001 com 3\% das preferências nacionais. Mesmo assim, não retornou ao patamar inicial de $1 \%$. O caso verdadeiramente significativo foi o do PT, conforme indica o Gráfico 2.

O Gráfico 2 demonstra que a identificação partidária com o PT entre os eleitores brasileiros aumentou quinze pontos percentuais em um período de doze anos, chegando em 2001 a 21\% da preferência nacional. A curva de identificação com o partido manteve-se ascendente durante quase todo o período, registrando queda apenas em 1994 e 1998, coincidentemente nos dois anos em que o partido perdeu as eleições para presidente, ainda no primeiro turno, para o PSDB. Tais números revelam o sucesso do PT em construir uma imagem consistente e que vem sendo amplamente identificada pela população em geral. O contraponto evidente é o caso do PSDB que esteve por oito anos à frente do governo nacional, mas não conseguiu, senão marginalmente, projetar sua imagem como responsável pelo governo. Essa tarefa ficou profundamente associada a FHC, coerente com o modelo personalista tradicional da dinâmica política brasileira.

Ainda no Gráfico 2 encontramos a evolução no percentual de eleitores que não se identificam com nenhum partido. Embora esse dado te- 
nha sido sujeito a uma irregularidade acentuada, foi possível perceber um relativo fortalecimento no sistema partidário, visto que $9 \%$ dos eleitores passaram a se identificar com algum partido ao longo do período. Considerando-se que o índice de preferência pelo PT elevou-se em quinze pontos percentuais e que a redução do índice dos que não possuem identificação partidária foi de nove pontos percentuais, é possível deduzir que parte das adesões ao PT foi proveniente de outros partidos.

Apesar da excepcionalidade do caso do PT, não se pode descartar a possibilidade de que outros partidos façam movimentos semelhantes, ou seja, venham a investir em estratégias coletivistas para a promoção de suas candidaturas. Nesse sentido, a tese de um franco e irreversível declínio dos partidos políticos pode, ao menos, ser problematizada. Embora mais da metade da população brasileira ainda não se identifique com nenhum partido, o desempenho do PT demonstrou que esse quadro pode ser revertido.

Uma das tendências da literatura acadêmica contemporânea é indicar, como responsável pela maioria das escolhas eleitorais recentes, um tipo de comportamento que tende a ser mais pragmático do que ideológico. Os eleitores das modernas democracias seriam mais bem informados e críticos com relação aos procedimentos e escolhas governamentais. Para esse tipo de eleitor, variáveis de caráter personalista como eficiência administrativa, probidade no uso do dinheiro público e credibilidade estariam substituindo considerações puramente ideológicas, assinalando um abandono das lealdades partidárias e, conseqüentemente, o surgimento de um tipo de eleitor predominantemente volátil. Nesse sentido, a tese da "mobilização cognitiva", ou o surgimento de um eleitor pragmaticamente orientado, teria como conseqüência necessária uma intensa individualização da participação política somada ao declínio dos partidos políticos (ver Dalton, 1984; Dalton e Kueckler, 1990; Inglehart, 1990) ${ }^{8}$.

Porém, tanto o crescimento da identificação partidária com o PT quanto seu progressivo sucesso eleitoral caminham na contramão dessa hipótese. Por outro lado, seria ingênuo pensar que o sucesso recente desse partido no cenário político brasileiro se deva a um comportamento ideológico por parte dos eleitores. É possível supor que a identificação do PT com uma espécie de alternativa eleitoral superior esteja associada a esse mesmo tipo de escolha pragmática, não refle- 
tindo necessariamente um comportamento individualista, mas sim identificando, na imagem coletiva de um partido, o fiador para a ação administrativa de seus representantes.

Uma primeira explicação para tal fenômeno pode ser encontrada no próprio discurso construído pelo PT que valoriza o partido como elaborador do projeto político em detrimento da imagem pessoal dos candidatos. À frente de governos municipais ou estaduais, as vantagens e desvantagens obtidas com o sucesso administrativo são apropriadas pelo partido governista, e não pelo grupo político associado ao chefe do Executivo ou a parlamentares individualmente. A experiência do PT revela que, menos que um declínio irreversível dos partidos, seria possível falar em uma reconfiguração de suas funções na arena representativa. A idéia de trabalho em equipe, afiançado por uma legenda que se projeta sobre a ação individual dos governantes, funcionaria como uma tentativa de reformulação do contrato representativo, resgatando a legitimidade e funcionalidade dos partidos nas democracias contemporâneas.

A análise da propaganda eleitoral gratuita, que será feita na próxima seção, visa constituir um quadro analítico que sirva de ponto de partida para uma investigação da evolução do discurso dos partidos políticos a partir de 1989. Assim, será possível perceber tendências de fortalecimento ou fragilização na imagem que é construída pelos partidos junto ao eleitorado. O objetivo é descobrir se o personalismo político se aprofundou diante do uso das novas tecnologias de comunicação, especialmente aquelas associadas à televisão, ou se está em curso a implementação de um novo modelo de comunicação entre partidos e eleitores, pautado pelo uso de estratégias coletivistas ${ }^{9}$.

\section{ESTRATÉGIAS COLETIVISTAS NO USO DO HGPE 2002}

Em artigo anterior, já foi discutido em detalhe as características do modelo brasileiro de propaganda política na televisão (Albuquerque e Dias, 2002). Aqui se enfatiza apenas o fato de a comunicação política no rádio e na televisão ser regulada pela legislação eleitoral, o que garante aos partidos acesso gratuito à propaganda política. Não existe no Brasil um modelo de propaganda política comercial (paga) na televisão, o que o diferencia dos padrões de profissionalização das campanhas eleitorais. 
Segundo Plasser (2001), uma das macrotendências do modelo de profissionalização está na importância que é destinada à propaganda paga na televisão, o que aumenta de forma significativa os orçamentos das campanhas eleitorais. A capacidade diferenciada dos candidatos de um mesmo partido em obter recursos que financiem suas campanhas interfere na distribuição de tempo na televisão a cada um deles, tornando esse acesso mais personalizado.

No caso brasileiro, a distribuição do tempo na televisão aos partidos obedece ao tamanho de suas bancadas nos respectivos Legislativos. O partido controla seu tempo na televisão, e a subdivisão do mesmo entre os candidatos depende de critérios distributivos que podem ser mais hierárquicos ou mais igualitários, dependendo da dinâmica das forças internas de cada partido. Assim, é o partido que determina se seus candidatos terão maior ou menor liberdade na divulgação de suas mensagens e, conseqüentemente, prescreve uma maior unidade ou fragmentação na própria imagem que projeta por via da televisão.

O objetivo deste texto é tecer algumas considerações preliminares acerca das estratégias comunicativas utilizadas pelos partidos brasileiros a partir de uma análise do HGPE veiculado no Rio Grande do Sul, durante a campanha de 2002. O procedimento metodológico adotado foi o do enquadramento dos programas partidários em planilhas que relacionavam estratégias de campanha ao partido ou ao candidato. As planilhas apresentavam variáveis diferenciadas para disputas majoritárias e proporcionais, visto que os estilos comunicativos das campanhas para cada um desses sistemas eleitorais exibiam peculiaridades que impediram uma homogeneização das categorias.

Algumas das variáveis eram comuns às planilhas aplicadas aos programas eleitorais para cargos majoritários e proporcionais:

1) partido: determina o partido do programa analisado;

2) cargo: determina o cargo em disputa no programa analisado (presidente, governador, senador, deputado federal, deputado estadual);

3) horário: determina se o programa foi veiculado no HGPE da tarde ou da noite;

4) uso da legenda: determina se, durante o programa, apareceu na tela a legenda ou símbolo do partido, da coligação (aliança de partidos) ou da própria campanha (como a imagem do governador ao fundo); 
5) propostas concretas: corresponde a um tipo de estratégia de campanha que aposta no voto prospectivo, estabelecendo metas de ação encampadas pelo candidato ou pelo partido (promessas de campanha).

As principais variáveis nas planilhas referiam-se a estratégias de campanha para cargos majoritários (presidente da República, governador e senador):

1) referência a realizações: corresponde a um tipo de estratégia de campanha que aposta no voto retrospectivo do eleitor, ou seja, se baseia no comportamento político pregresso, seja do candidato, seja do partido;

2) ideologia: registro de idéias, valores e crenças do candidato ou do partido durante o programa eleitoral;

3) capacidade: investimento na estratégia de convencimento do eleitor quanto à capacidade do candidato ou do partido para o exercício das funções governamentais;

4) ataque ao adversário: corresponde a um tipo de estratégia de campanha que se baseia no desmonte da imagem do candidato ou do partido adversário.

As principais variáveis nas planilhas referiam-se a estratégias de campanha para cargos proporcionais (deputados federal e estadual):

1) referência coletiva: utilizada quando um ou mais candidatos fazem referência direta (verbal) ao partido do qual fazem parte, ou se referem aos candidatos majoritários (presidente, governador ou senador) do mesmo partido ou da aliança de partidos à qual pertencem;

2) introdução pelo partido: traduz-se em uma apresentação dos candidatos, no início do programa, feita em nome do partido, colocando sua imagem à frente dos candidatos;

3) fidelidade partidária: utilizada quando um ou mais candidatos enfatiza a fidelidade ao partido, seja como um aspecto positivo, seja como uma dimensão negativa da dinâmica política;

4) voto de legenda: verificada quando, durante o programa, é possível notar um incentivo direto ao voto na legenda partidária, ou quando o partido utiliza um "puxador de legenda"; 
5) candidatos apresentados: é uma variável que determina o número de candidatos apresentados por programa, buscando verificar a distribuição do tempo de cada partido entre seus candidatos.

Depois de classificados segundo as variáveis das planilhas, cada programa de cada partido foi tomado como uma unidade de análise e lançado no Statistical Package Social Science - SPSS, o que permitiu montar um panorama das múltiplas estratégias utilizadas pelos partidos em suas campanhas na televisão, assim como compará-los mutuamente.

As análises efetuadas a seguir tornarão mais claros os procedimentos e serão separadas em duas dimensões: na primeira, intrapartidária, analisarei as estratégias comunicativas dos partidos em função dos cargos em disputa; na segunda, interpartidária, examinarei as estratégias comunicativas do ponto de vista sistêmico, observando as diferenças entre os comportamentos das agremiações ${ }^{10}$.

\section{Análise a partir da Dimensão Intrapartidária}

\section{O uso da legenda}

O uso de legenda ou símbolos indicativos de uma identidade coletiva contribui para a construção de uma imagem de unidade, em face da fragmentação de cargos, abrangência de atuação (nacional ou regional), linguagens, propósitos e metas. Quanto maior o uso desses símbolos coletivos, maiores serão os indícios de que o partido se empenha em transmitir uma imagem de coerência interna aos eleitores ${ }^{11}$.

O uso da legenda partidária é o indício mais consistente da submissão das diferentes propostas a um projeto coletivo. As legendas da coligação ou símbolos da campanha também são indicativos de uma coerência interna, mas tornam a imagem do partido difusa, pois mesclada à imagem de outros partidos ou à conjuntura específica que cerca aquela eleição. Essas estratégias podem ser utilizadas também de forma combinada, ou seja, legenda partidária e da coligação (em separado) ou símbolos da campanha. A estratégia individualista extrema estará na ausência de qualquer símbolo coletivo na propaganda do(s) candidato(s).

A seguir serão analisadas as estratégias relativas ao uso da legenda utilizadas pelos seguintes partidos: PT e PPS, que apresentaram can- 
didaturas para todos os cargos em disputa; PMDB e PSDB, sendo que o primeiro não apresentou candidato ao cargo de presidente, e o segundo não apresentou candidato ao cargo de governador.

Tabela 1

Partido dos Trabalhadores - PT

Uso da Legenda

\begin{tabular}{|c|c|c|c|c|c|c|c|c|}
\hline & & Partido & $\begin{array}{l}\text { Partido } \\
\text { e Coli- } \\
\text { gação }\end{array}$ & $\begin{array}{l}\text { Partido e } \\
\text { Campanha }\end{array}$ & $\begin{array}{c}\text { Campanha e/ou } \\
\text { Coligação }\end{array}$ & Todas & $\begin{array}{c}\text { Nenhu- } \\
\text { ma }\end{array}$ & Total \\
\hline \multirow{3}{*}{ Presidente } & & 15 & 5 & 2 & 6 & 8 & & 36 \\
\hline & $\%$ Cargo & $41,7 \%$ & $13,9 \%$ & $5,6 \%$ & $16,7 \%$ & $22,2 \%$ & & $100,0 \%$ \\
\hline & $\%$ Legenda & $65,2 \%$ & $50,0 \%$ & $3,7 \%$ & $37,5 \%$ & $32,0 \%$ & & $27,5 \%$ \\
\hline \multirow[t]{3}{*}{ Governador } & & 5 & 4 & 8 & 3 & 13 & 2 & 35 \\
\hline & $\%$ Cargo & $14,3 \%$ & $11,4 \%$ & $22,9 \%$ & $8,6 \%$ & $37,1 \%$ & $5,7 \%$ & $100,0 \%$ \\
\hline & $\%$ Legenda & $21,7 \%$ & $40,0 \%$ & $14,8 \%$ & $18,7 \%$ & $52,0 \%$ & $66,7 \%$ & $26,7 \%$ \\
\hline \multirow[t]{3}{*}{ Senador } & & 3 & 1 & 13 & 7 & 1 & & 25 \\
\hline & $\%$ Cargo & $12,0 \%$ & $4,0 \%$ & $52,0 \%$ & $28,0 \%$ & $4,0 \%$ & & $100,0 \%$ \\
\hline & $\%$ Legenda & $13,0 \%$ & $10,0 \%$ & $24,1 \%$ & $43,8 \%$ & $4,0 \%$ & & $19,1 \%$ \\
\hline \multirow{3}{*}{$\begin{array}{l}\text { Deputado } \\
\text { Federal }\end{array}$} & & & & 16 & & & 1 & 17 \\
\hline & $\%$ Cargo & & & $94,1 \%$ & & & $5,9 \%$ & $100,0 \%$ \\
\hline & $\%$ Legenda & & & $29,6 \%$ & & & $33,3 \%$ & $13,0 \%$ \\
\hline \multirow{3}{*}{$\begin{array}{l}\text { Deputado } \\
\text { Estadual }\end{array}$} & & & & 15 & & 3 & & 18 \\
\hline & $\%$ Cargo & & & $83,3 \%$ & & $16,7 \%$ & & $100,0 \%$ \\
\hline & $\%$ Legenda & & & $27,8 \%$ & & $12,0 \%$ & & $13,7 \%$ \\
\hline Total & $\mid \begin{array}{c}\% \text { Cargo } \\
\% \text { Legenda }\end{array}$ & $\begin{array}{c}23 \\
17,6 \% \\
100,0 \%\end{array}$ & $\begin{array}{c}10 \\
7,6 \% \\
100,0 \%\end{array}$ & $\begin{array}{c}54 \\
41,2 \% \\
100,0 \%\end{array}$ & $\begin{array}{c}16 \\
12,2 \% \\
100,0 \%\end{array}$ & $\begin{array}{c}25 \\
19,1 \% \\
100,0 \%\end{array}$ & $\begin{array}{c}3 \\
2,3 \% \\
100,0 \%\end{array}$ & $\begin{array}{c}131 \\
100,0 \% \\
100,0 \%\end{array}$ \\
\hline
\end{tabular}

Fonte: HGPE 2002. Dados coletados pela autora.

Pela Tabela 1 é possível verificar o uso da legenda que foi feito pelo PT nas estratégias comunicativas para os distintos cargos em disputa. É notável o uso extensivo da legenda partidária, presente em quase todos os casos analisados (85,5\%). Nas campanhas para presidente e governador, os casos em que a legenda partidária esteve ausente da propaganda veiculada, ou mesclada às legendas de outros partidos que compunham a aliança, foi de $16,7 \%$ e $14,3 \%$, respectivamente ${ }^{12}$. Nas campanhas para cargos proporcionais, o uso foi ainda mais significativo: apenas em 5,9\% das propagandas para deputado federal não houve alguma referência explícita à legenda do partido. Somente no caso da campanha para senador registrou-se um percentual importante para a ausência da legenda partidária: $28 \%$ das propagandas 
analisadas enfatizavam exclusivamente a legenda da coligação e/ou os símbolos da campanha.

É curioso notar que o uso exclusivo da legenda partidária foi uma estratégia utilizada muito mais na campanha nacional do que nas campanhas regionais: das propagandas analisadas que continham apenas a legenda do partido, 65,2\% eram para o cargo de presidente; $21,7 \%$ para o cargo de governador; $13 \%$ para senador; não havendo incidência desse tipo de estratégia para os cargos de deputados federal e estadual. Nestes dois últimos cargos, vale notar que a presença da sigla partidária vinha sempre acompanhada de símbolos da campanha, os quais promoviam o candidato a governador Tarso Genro.

Tabela 2

Partido Popular Socialista - PPS

Uso da Legenda

\begin{tabular}{|c|c|c|c|c|c|c|c|c|}
\hline & & Partido & $\begin{array}{l}\text { Partido e } \\
\text { Coligação }\end{array}$ & $\begin{array}{c}\text { Partido e } \\
\text { Campanha }\end{array}$ & $\begin{array}{c}\text { Campanha } \\
\text { e/ou Coligação }\end{array}$ & Todas & Nenhuma & Total \\
\hline \multirow{3}{*}{$\begin{array}{l}\text { Presi- } \\
\text { dente }\end{array}$} & & & 1 & & 27 & & & 28 \\
\hline & $\%$ Cargo & & $3,6 \%$ & & $96,5 \%$ & & & $100,0 \%$ \\
\hline & $\%$ Legenda & & $100,0 \%$ & & $28,7 \%$ & & & $24,3 \%$ \\
\hline \multirow{3}{*}{$\begin{array}{l}\text { Gover- } \\
\text { nador }\end{array}$} & & & & & 19 & 3 & 5 & 27 \\
\hline & $\%$ Cargo & & & & $70,3 \%$ & $11,1 \%$ & $18,5 \%$ & $100,0 \%$ \\
\hline & \% Legenda & & & & $20,2 \%$ & $100,0 \%$ & $35,7 \%$ & $23,5 \%$ \\
\hline \multirow[t]{3}{*}{ Senador } & & & & & 17 & & 8 & 25 \\
\hline & $\%$ Cargo & & & & $68,0 \%$ & & $32,0 \%$ & $100,0 \%$ \\
\hline & $\%$ Legenda & & & & $18,1 \%$ & & $57,1 \%$ & $21,7 \%$ \\
\hline \multirow{3}{*}{$\begin{array}{l}\text { Deputa- } \\
\text { do Fede- } \\
\text { ral }\end{array}$} & & & & & 16 & & 1 & 17 \\
\hline & $\%$ Cargo & & & & $94,1 \%$ & & $5,9 \%$ & $100,0 \%$ \\
\hline & \% Legenda & & & & $17,0 \%$ & & $7,1 \%$ & $14,8 \%$ \\
\hline \multirow{3}{*}{$\begin{array}{l}\text { Deputa- } \\
\text { do Esta- } \\
\text { dual }\end{array}$} & & & & 3 & 15 & & & 18 \\
\hline & $\%$ Cargo & & & $16,7 \%$ & $83,3 \%$ & & & $100,0 \%$ \\
\hline & $\%$ Legenda & & & $100,0 \%$ & $16,0 \%$ & & & $15,7 \%$ \\
\hline \multirow[t]{3}{*}{ Total } & & & 1 & 3 & 94 & 3 & 14 & 115 \\
\hline & \% Cargo & & $0,9 \%$ & $2,6 \%$ & $81,7 \%$ & $2,6 \%$ & $12,2 \%$ & $100,0 \%$ \\
\hline & $\%$ Legenda & & $100,0 \%$ & $100,0 \%$ & $100,0 \%$ & $100,0 \%$ & $100,0 \%$ & $100,0 \%$ \\
\hline
\end{tabular}

Fonte: HGPE 2002. Dados coletados pela autora.

O uso da legenda nas estratégias comunicativas do PPS caracteriza um modelo muito mais personalista do que o verificado na campanha do PT. A legenda do PPS foi utilizada de forma apenas marginal e sempre coligada com outros símbolos, fosse da campanha, fosse da coligação. Apenas em 6,1\% dos casos analisados, a legenda partidária 
foi utilizada durante a campanha. As estratégias mais utilizadas na promoção de uma imagem coletiva se deram por meio de símbolos da campanha e/ ou legenda da coligação $(81,7 \%)$. Vale ressaltar que, em $12,2 \%$ dos casos, não apareceu nenhuma referência coletiva, especialmente nas campanhas majoritárias regionais (governador e senador). O candidato a governador pelo Rio Grande do Sul, o ex-governador Antônio Brito, empenhou-se em não vincular sua imagem à do partido, fazendo durante a campanha inúmeras referências ao potencial desagregador dos interesses estaduais que a fidelidade partidária acarreta.

A campanha da candidatura de Ciro Gomes ao cargo de presidente foi a que mais se empenhou na promoção de uma imagem coletiva, mas mesmo assim se deteve, sobretudo, em símbolos da própria campanha, tornando bastante similar as estratégias utilizadas nos âmbitos nacional e regional. É importante ressaltar que o desempenho eleitoral do partido foi muito fraco para todos os cargos: mesmo o ex-governador Antônio Brito, muito popular entre os antipetistas do Rio Grande do Sul, perdeu a vaga no segundo turno para o candidato Germano Rigotto (PMDB), que acabou vencendo as eleições.

O uso da legenda partidária pelo PMDB foi bastante significativo: em $49,5 \%$ dos casos analisados, o partido fez uso de sua legenda durante a campanha eleitoral de 2002. O uso exclusivo da legenda partidária, porém, foi verificado em um pequeno número de casos, 9,9\% do total, tendo sido mais verificado nas campanhas para senador e deputado estadual. O aparecimento de símbolos de campanha, normalmente relativos à candidatura de Germano Rigotto a governador, foi ainda mais expressivo: em 85,7\% dos programas analisados, houve alguma referência à campanha eleitoral do partido. Nos programas relativos à campanha de governador, verificou-se a presença de símbolos de campanha em $85,7 \%$ dos casos. É importante ressaltar ainda que, em apenas 4,4\% dos programas analisados, não houve nenhuma referência à identidade coletiva dos candidatos.

O PMDB é um dos partidos que mais se empenham na construção de uma imagem coletiva junto aos eleitores. Normalmente, o partido faz referência à sua trajetória, identificando-se com as lutas pela redemocratização brasileira e registrando seu papel no processo de transição. Coincidentemente, é o partido em segundo lugar na preferência dos eleitores, como vimos acima, mantendo um percentual em torno de 
Projeção da Imagem Partidária nas Estratégias de Campanha na Televisão...

Tabela 3

Partido do Movimento Democrático Brasileiro - PMDB

Uso da Legenda

\begin{tabular}{|c|c|c|c|c|c|c|c|c|}
\hline & & Partido & $\begin{array}{l}\text { Partido e } \\
\text { Coligação }\end{array}$ & $\begin{array}{c}\text { Partido e } \\
\text { Campa- } \\
\text { nha }\end{array}$ & $\begin{array}{c}\text { Campanha } \\
\text { e/ou Coligação }\end{array}$ & Todas & $\begin{array}{c}\text { Nenhu- } \\
\text { ma }\end{array}$ & Total \\
\hline \multirow[t]{3}{*}{ Governador } & & 1 & 1 & 3 & 24 & 3 & 3 & 35 \\
\hline & $\%$ Cargo & $2,9 \%$ & $2,9 \%$ & $8,6 \%$ & $68,5 \%$ & $8,6 \%$ & $8,6 \%$ & $100,0 \%$ \\
\hline & $\%$ Legenda & $11,1 \%$ & $100,0 \%$ & $14,3 \%$ & $57,1 \%$ & $21,4 \%$ & $75,0 \%$ & $38,5 \%$ \\
\hline \multirow[t]{3}{*}{ Senador } & & 5 & & 6 & 6 & 4 & & 21 \\
\hline & $\%$ Cargo & $23,8 \%$ & & $28,6 \%$ & $28,6 \%$ & $19,0 \%$ & & $100,0 \%$ \\
\hline & $\%$ Legenda & $55,6 \%$ & & $28,6 \%$ & $14,3 \%$ & $28,6 \%$ & & $23,1 \%$ \\
\hline \multirow{3}{*}{$\begin{array}{l}\text { Deputado Fe- } \\
\text { deral }\end{array}$} & & & & 2 & 7 & 7 & 1 & 17 \\
\hline & $\%$ Cargo & & & $11,8 \%$ & $41,2 \%$ & $41,2 \%$ & $5,9 \%$ & $100,0 \%$ \\
\hline & $\%$ Legenda & & & $9,5 \%$ & $16,7 \%$ & $50,0 \%$ & $25,0 \%$ & $18,7 \%$ \\
\hline \multirow[t]{2}{*}{$\begin{array}{l}\text { Deputado } \\
\text { Estadual }\end{array}$} & $\%$ Cargo & $\begin{array}{c}3 \\
16,7 \% \\
\end{array}$ & & $\begin{array}{c}10 \\
55,6 \% \\
\end{array}$ & $\begin{array}{c}5 \\
27,8 \% \\
\end{array}$ & & & $\begin{array}{c}18 \\
100,0 \% \\
\end{array}$ \\
\hline & $\%$ Legenda & $33,3 \%$ & & $47,6 \%$ & $11,9 \%$ & & & $19,8 \%$ \\
\hline \multirow[t]{3}{*}{ Total } & & 9 & 1 & 21 & 42 & 14 & 4 & 91 \\
\hline & $\%$ Cargo & $9,9 \%$ & $1,1 \%$ & $23,1 \%$ & $46,2 \%$ & $15,4 \%$ & $4,4 \%$ & $100,0 \%$ \\
\hline & $\%$ Legenda & $100,0 \%$ & $100,0 \%$ & $100,0 \%$ & $100,0 \%$ & $100,0 \%$ & $100,0 \%$ & $100,0 \%$ \\
\hline
\end{tabular}

Fonte: HGPE 2002. Dados coletados pela autora.

$12 \%$. Entretanto, ainda é prematuro fazer correlações entre a construção da imagem dos partidos durante a campanha e seu status na preferência do eleitor. Outros dados ainda precisam ser analisados de modo a fornecer subsídios analíticos mais consistentes.

O uso da legenda partidária nos programas do PSDB também foi amplamente constatado: em 46,8\% dos casos analisados, a legenda do partido estava presente. $\mathrm{O}$ uso exclusivo da legenda seguiu o mesmo padrão do PMDB: ocorreu em apenas 9,8\% dos casos.

A campanha do PSDB apresentou discrepância entre os âmbitos nacional e regional no que concerne ao uso da legenda partidária, que foi muito mais evidente na campanha regional. Na campanha para presidente, a presença da legenda partidária verificou-se em apenas 13,9\% dos casos; em 97,2\% dos casos, apareciam símbolos coletivos associados à campanha de José Serra. O uso de referenciais coletivos pela campanha regional apresentou uma distribuição mais homogênea: tanto o partido quanto os símbolos de campanha e coligação estavam presentes em proporções semelhantes. Entretanto, no cômputo geral, 
Tabela 4

Partido da Social Democracia Brasileira - PSDB

Uso da Legenda

\begin{tabular}{|c|c|c|c|c|c|c|c|c|}
\hline & & Partido & $\begin{array}{l}\text { Partido e } \\
\text { Coligação }\end{array}$ & $\begin{array}{c}\text { Partido e } \\
\text { Campa- } \\
\text { nha }\end{array}$ & $\begin{array}{c}\text { Campa- } \\
\text { nha e/ou } \\
\text { Coligação }\end{array}$ & Todas & Nenhuma & Total \\
\hline \multirow[t]{3}{*}{ Presidente } & & 1 & & & 31 & 4 & & 36 \\
\hline & $\%$ Cargo & $2,8 \%$ & & & $86,1 \%$ & $11,1 \%$ & & $100,0 \%$ \\
\hline & $\%$ Legenda & $11,1 \%$ & & & $63,3 \%$ & $44,4 \%$ & & $39,1 \%$ \\
\hline \multirow[t]{3}{*}{ Senador } & & 4 & 1 & 3 & 8 & 5 & & 21 \\
\hline & $\%$ Cargo & $19,0 \%$ & $4,8 \%$ & $14,3 \%$ & $38,1 \%$ & $23,8 \%$ & & $100,0 \%$ \\
\hline & $\%$ Legenda & $44,4 \%$ & $100,0 \%$ & $12,5 \%$ & $16,3 \%$ & $55,6 \%$ & & $22,8 \%$ \\
\hline \multirow{3}{*}{$\begin{array}{l}\text { Deputado } \\
\text { Federal }\end{array}$} & & 3 & & 9 & 5 & & & 17 \\
\hline & \% Cargo & $17,6 \%$ & & $52,9 \%$ & $29,4 \%$ & & & $100,0 \%$ \\
\hline & $\%$ Legenda & $33,3 \%$ & & $37,5 \%$ & $10,2 \%$ & & & $18,5 \%$ \\
\hline \multirow{3}{*}{$\begin{array}{l}\text { Deputado } \\
\text { Estadual }\end{array}$} & & 1 & & 12 & 5 & & & 18 \\
\hline & \% Cargo & $5,6 \%$ & & $66,7 \%$ & $27,8 \%$ & & & $100,0 \%$ \\
\hline & $\%$ Legenda & $11,1 \%$ & & $50,0 \%$ & $10,2 \%$ & & & $19,6 \%$ \\
\hline \multirow[t]{3}{*}{ Total } & & 9 & 1 & 24 & 49 & 9 & & 92 \\
\hline & \% Cargo & $9,8 \%$ & $1,1 \%$ & $26,1 \%$ & $53,2 \%$ & $9,8 \%$ & & $100,0 \%$ \\
\hline & \% Legenda & $100,0 \%$ & $100,0 \%$ & $100,0 \%$ & $100,0 \%$ & $100,0 \%$ & & $100,0 \%$ \\
\hline
\end{tabular}

Fonte: HGPE 2002. Dados coletados pela autora.

foi possível perceber um esforço maior do PSDB em identificar-se com símbolos coletivos mais circunstanciais, ou seja, associados à campanha daquele ano; em 89,1\% dos casos, esses símbolos estiveram presentes.

\section{Uma Perspectiva Sistêmica}

\section{Investimento no voto retrospectivo}

O voto retrospectivo é aquele que é motivado por ações políticas passadas. Neste caso, o processo de escolha eleitoral passa por uma avaliação crítica do comportamento político pregresso do candidato ou do partido em campanha. Em seus programas televisivos, os partidos podem investir nesse tipo de voto, dedicando-se a mostrar ao eleitor políticas bem-sucedidas realizadas pelo candidato ou pelo próprio partido. Certamente que o uso desse recurso será maior entre partidos que já ocuparam cargos políticos de destaque, principalmente no Poder Executivo. Os partidos ou candidatos podem também chamar a atenção do eleitor para projetos de lei de sua autoria que se transfor- 
maram em políticas importantes, seja para o investimento público seja para regulações estatais. Assim, partidos sem representação ou com baixo grau de representação política praticamente não utilizam esse tipo de estratégia.

A seguir, apresento o uso desse tipo de estratégia de captação de votos pelos partidos. É importante ressaltar que essa questão foi colocada apenas nas planilhas relativas a cargos majoritários.

Tabela 5

Voto Retrospectivo

Referência a Realizações

\begin{tabular}{l|c|c|c|c}
\hline & Partido & Candidato & Nenhum & Total \\
\hline PT & $\begin{array}{c}17 \\
(17,7 \%)\end{array}$ & $\begin{array}{c}12 \\
(12,5 \%)\end{array}$ & $\begin{array}{c}67 \\
(69,8 \%)\end{array}$ & $\begin{array}{c}96 \\
(100,0 \%)\end{array}$ \\
\hline PMDB & & 8 & 48 & 56 \\
$(14,3 \%)$ & $(85,7 \%)$ & $(100,0 \%)$ \\
\hline PSDB & & 30 & 27 & 57 \\
& 1 & $(52,6 \%)$ & $(47,4 \%)$ & $(100,0 \%)$ \\
\hline PPS & $(1,3 \%)$ & $(27,5 \%)$ & $(71,3 \%)$ & $(100,0 \%)$ \\
\hline PPB & & 4 & 48 & 52 \\
& 7 & $(7,7 \%)$ & $(92,3 \%)$ & $(100,0 \%)$ \\
\hline PSB & $(9,2 \%)$ & $(22,4 \%)$ & $(68,4 \%)$ & $(100,0 \%)$ \\
\hline Total & $\mathbf{2 5}$ & $\mathbf{9 3}$ & $\mathbf{2 9 9}$ & $\mathbf{4 1 7}$ \\
& $\mathbf{( 6 , 0 \% )}$ & $\mathbf{( 2 2 , 3 \% )}$ & $\mathbf{( 7 1 , 7 \% )}$ & $\mathbf{( 1 0 0 , 0 \% )}$ \\
\hline
\end{tabular}

Fonte: HGPE 2002. Dados coletados pela autora.

Em uma perspectiva sistêmica, apenas 28,3\% das estratégias de campanha destinaram-se ao investimento dos partidos estimular no eleitor um tipo de voto retrospectivo. Individualmente, apenas o PSDB situou-se significativamente acima dessa média: $52,6 \%$ dos casos analisados continham referências a realizações pregressas. Entretanto, é importante lembrar que o PSDB esteve à frente do governo federal por oito anos, podendo ser mais beneficiado por esse tipo de estratégia do que qualquer outro partido. É curioso notar que nenhuma dessas referências a realizações foi atribuída ao partido, e sim ao candidato. Cabe ainda ressaltar que a campanha de José Serra, ex-ministro da Saúde, associou amplamente as realizações do Ministério à sua pessoa, e guardava um relativo distanciamento com relação ao governo que terminava. 
Os partidos que menos utilizaram a estratégia do estímulo ao voto retrospectivo foram o PPB $(7,7 \%)$ e o PMDB $(14,3 \%)$. Em ambos os casos, as referências a realizações sempre estavam associadas à imagem do candidato. Vale lembrar que ambos os partidos não apresentaram candidatos à Presidência da República, ou seja, os dados aqui mostrados referem-se ao plano estadual (candidaturas ao governo do estado e ao Senado Federal).

$\mathrm{O} P \mathrm{PT}$ e o PSB ficaram próximos à média: o primeiro utilizou a estratégia do estímulo ao voto retrospectivo em $30,2 \%$ dos casos analisados, e o segundo em $31,6 \%$. A diferença entre esses dois partidos está, principalmente, no modo como se apropriaram das realizações passadas. Embora tanto um quanto o outro mesclassem estratégias coletivistas e individualistas, associando a realização passada ora ao partido, ora ao candidato, o PT utilizou proporcionalmente mais estratégias de natureza coletivista $(17,7 \%)$, enquanto o PSB lançou mão desse tipo de estratégia em $9,2 \%$ dos casos analisados.

Se tomarmos a estratégia de voto retrospectivo como universo da análise, perceberemos que, em $58,6 \%$ das vezes que o PT utilizou esse tipo de estratégia, as realizações mencionadas eram atribuídas ao partido e não ao candidato. Mais significativo, entretanto, é quando se desmembra esse dado por cargos: nas campanhas para presidente e governador, sempre que o programa fez referência a realizações passadas, a autoria das mesmas era atribuída ao partido, nunca ao candidato. Somente na campanha ao Senado foi possível verificar uma expressiva atribuição de mérito ao candidato - em 92,3\% das vezes em que se registrou referência a realizações passadas, a autoria foi atribuída diretamente ao candidato a senador ${ }^{13}$.

Se fizermos o mesmo para analisar os dados do PSB, perceberemos que, em $29,2 \%$ das vezes em que se registrou o estímulo ao voto retrospectivo, o mérito das políticas realizadas foi atribuído ao partido. $\mathrm{O}$ panorama de estratégias, neste caso, fica ainda mais interessante, pois a diferença entre as estratégias nacional e regional é marcante. $\mathrm{Na}$ análise dos programas para o cargo de presidente, foi possível perceber que, em $60,7 \%$ dos casos, houve investimento no voto retrospectivo; todas as realizações mencionadas foram atribuídas ao candidato Anthony Garotinho. Na análise dos programas para os cargos de governador e senador, o uso da estratégia foi bem menos significativo: $26,1 \%$ e 4,0\%, respectivamente. Entretanto, os resultados são dia- 
metralmente opostos, ou seja, em todos os casos as realizações citadas durante os programas eram atribuídas ao partido. Note-se que o candidato Garotinho não era um membro histórico do PSB; na verdade, seu ingresso neste partido era recente e hoje ele já não mais integra o PSB, por decisão do próprio partido. Além disso, no Rio Grande do Sul, o PSB integrava a Frente Popular, aliança encabeçada pelo PT, que governava a capital, Porto Alegre, desde 1989. Tal aliança pode ser a responsável pela semelhança entre as estratégias do PT e do PSB em âmbito local ${ }^{14}$.

\section{Investimento no voto prospectivo}

O voto prospectivo é aquele que se baseia nas propostas dos partidos ou candidatos. A motivação para esse tipo de voto é a crença em que determinadas propostas são superiores a outras, seja pelo benefício que trazem, seja por sua coerência interna e exeqüibilidade. Este é um tipo de estratégia que se encontra disponível para qualquer partido, por mais recente que seja o seu ingresso na dinâmica política eleitoral. Essa variável esteve presente nas planilhas aplicadas tanto a cargos majoritários quanto proporcionais, e seus resultados estão dispostos na tabela a seguir.

Tabela 6

Voto Prospectivo

Propostas Concretas

\begin{tabular}{l|c|c|c|c|c}
\hline & Partido & Candidato & Ambos & Nenhum & Total \\
\hline PT & 20 & 51 & 13 & 47 \\
$(15,3 \%)$ & $(38,9 \%)$ & $(9,9 \%)$ & $(35,9 \%)$ & $\begin{array}{c}131 \\
(100,0 \%)\end{array}$ \\
\hline PMDB & & $\begin{array}{c}67 \\
(73,6 \%)\end{array}$ & $\begin{array}{c}1 \\
(1,1 \%)\end{array}$ & $\begin{array}{c}23 \\
(25,3 \%)\end{array}$ & $\begin{array}{c}91 \\
(100,0 \%)\end{array}$ \\
\hline PSDB & & 73 & 2 & 17 & 92 \\
& $(79,3 \%)$ & $(2,2 \%)$ & $(18,5 \%)$ & $(100,0 \%)$ \\
\hline PPS & 1 & 79 & & 35 & 115 \\
& $(0,9 \%)$ & $(68,7 \%)$ & & $(30,4 \%)$ & $(100,0 \%)$ \\
\hline PPB & 1 & 54 & 4 & 27 & 86 \\
& $(1,2 \%)$ & $(62,8 \%)$ & $(4,7 \%)$ & $(31,4 \%)$ & $(100,0 \%)$ \\
\hline PSB & 7 & 46 & 1 & 54 & 108 \\
\hline Total & $(6,5 \%)$ & $(42,6 \%)$ & $(0,9 \%)$ & $(50,0 \%)$ & $(100,0 \%)$ \\
\hline & $\mathbf{2 9}$ & $\mathbf{3 7 0}$ & $\mathbf{2 1}$ & $\mathbf{2 0 3}$ & $\mathbf{6 2 3}$ \\
& $(\mathbf{4 , 6 \% )}$ & $\mathbf{( 5 9 , 4 \% )}$ & $\mathbf{( 3 , 4 \% )}$ & $\mathbf{( 3 2 , 6 \% )}$ & $\mathbf{( 1 0 0 , 0 \% )}$ \\
\hline
\end{tabular}

Fonte: HGPE 2002. Dados coletados pela autora. 
O estímulo ao voto prospectivo demonstrou ser uma estratégia amplamente utilizada pelos partidos. Em média, 67,4\% dos programas analisados continham propostas concretas de políticas públicas. Entretanto, a estratégia dos partidos, tomados individualmente, variou bastante. Os partidos que mais utilizaram esse tipo de estratégia foram o PSDB (81,5\%) e o PMDB (74,7\%), e o que menos a utilizou foi o PSB (50\%). Ou seja, o partido que menos usou a estratégia de investimento no voto prospectivo utilizou-a em metade dos programas analisados, o que registra a importância que as promessas de campanha têm na propaganda eleitoral televisiva no Brasil.

A principal diferença entre elas, no entanto, está na autoria que é atribuída aos projetos, ou seja, se são propostas do partido ou do candidato. O PT foi quem mais apresentou propostas em seu próprio nome - em $25,2 \%$ dos programas analisados foi divulgada alguma proposta de autoria do partido. Se considerarmos o uso do voto prospectivo como universo da análise, verificaremos que, em 39,3\% das vezes em que o PT fez uso dessa estratégia, ela era de natureza coletivista.

O PPS $(0,9 \%)$, o PMDB $(1,1 \%)$ e o PSDB $(2,2 \%)$ foram os partidos que menos se identificaram diretamente com propostas de campanha de seus candidatos, ou seja, foram aqueles que menos fizeram uso da estratégia coletivista no estímulo ao voto prospectivo nos casos analisados.

\section{Valorização da capacidade técnica ou política}

Um outro tipo de estratégia que aqui será analisado é o da valorização da competência ou de um saber especializado do partido ou do candidato para gerir os negócios públicos. Este é um tipo de estratégia que normalmente é associado ao declínio das ideologias políticas em um mundo de profissionalização e especialização. A questão que aqui se coloca é se existe a possibilidade de os partidos políticos vincularem suas imagens a critérios tão personalistas quanto os de competência e especialização. Em caso afirmativo, é possível supor a sobrevivência dos partidos em um universo, senão livre, de reduzida influência das ideologias. A Tabela 7 mostra como a propaganda dos partidos na televisão lidou com a demanda do eleitorado por uma maior capacidade técnica entre os gestores públicos. 
Projeção da Imagem Partidária nas Estratégias de Campanha na Televisão...

Tabela 7

Valorização da Competência

Técnica ou Política

\begin{tabular}{|c|c|c|c|c|c|}
\hline & Partido & Candidato & Ambos & Nenhum & Total \\
\hline PT & $\begin{array}{c}13 \\
(13,5 \%) \\
\end{array}$ & $\begin{array}{c}24 \\
(25,0 \%) \\
\end{array}$ & $\begin{array}{c}7 \\
(7,3 \%) \\
\end{array}$ & $\begin{array}{c}52 \\
(54,2 \%) \\
\end{array}$ & $\begin{array}{c}96 \\
(100,0 \%) \\
\end{array}$ \\
\hline PMDB & $\begin{array}{c}2 \\
(3,6 \%) \\
\end{array}$ & $\begin{array}{c}37 \\
(66,1 \%) \\
\end{array}$ & & $\begin{array}{c}17 \\
(30,4 \%)\end{array}$ & $\begin{array}{c}56 \\
(100,0 \%) \\
\end{array}$ \\
\hline PSDB & & $\begin{array}{c}43 \\
(75,4 \%) \\
\end{array}$ & & $\begin{array}{c}14 \\
(24,6 \%) \\
\end{array}$ & $\begin{array}{c}57 \\
(100,0 \%) \\
\end{array}$ \\
\hline PPS & $\begin{array}{c}1 \\
(1,3 \%) \\
\end{array}$ & $\begin{array}{c}37 \\
(46,3 \%) \\
\end{array}$ & & $\begin{array}{c}42 \\
(52,5 \%) \\
\end{array}$ & $\begin{array}{c}80 \\
(100,0 \%) \\
\end{array}$ \\
\hline PPB & & $\begin{array}{c}19 \\
(36,5 \%) \\
\end{array}$ & $\begin{array}{c}1 \\
(1,9 \%)\end{array}$ & $\begin{array}{c}32 \\
(61,5 \%) \\
\end{array}$ & $\begin{array}{c}52 \\
(100,0 \%) \\
\end{array}$ \\
\hline PSB & $\begin{array}{c}8 \\
(10,5 \%) \\
\end{array}$ & $\begin{array}{c}25 \\
(32,9 \%) \\
\end{array}$ & & $\begin{array}{c}43 \\
(56,6 \%) \\
\end{array}$ & $\begin{array}{c}76 \\
(100,0 \%) \\
\end{array}$ \\
\hline Total & $\begin{array}{c}24 \\
(5,7 \%)\end{array}$ & $\begin{array}{c}185 \\
(44,4 \%)\end{array}$ & $\begin{array}{c}8 \\
(1,9 \%)\end{array}$ & $\begin{array}{c}200 \\
(48 \%)\end{array}$ & $\begin{array}{c}417 \\
(100,0 \%)\end{array}$ \\
\hline
\end{tabular}

Fonte: HGPE 2002. Dados coletados pela autora.

Em média, 52\% dos programas analisados continham alguma mensagem mediante a qual partidos ou candidatos se identificavam com critérios de competência e/ou saber especializado; percentual superior ao investido em voto retrospectivo (28\%). Os partidos que mais fizeram uso dessa estratégia foram o PSDB $(75,4 \%)$ e o PMDB $(69,7 \%)$. O partido que mais demonstrou ser refratário a esse tipo de estratégia foi o PPB (atual PP), e mesmo assim a empregou em 38,4\% dos programas analisados, o que demonstra a força da mesma na propaganda eleitoral veiculada na televisão brasileira.

Mais uma vez, uma curiosa discrepância apresenta-se com relação à fonte da competência ou saber técnico anunciado. Os partidos que mais se utilizam dessa estratégia pouco a atribuem ao partido; em apenas 3,6\% dos casos analisados do PMDB, o partido era a fonte de capacidade técnica, enquanto no PSDB não houve registros nesse sentido. Os partidos que com maior freqüência associam a competência à imagem do partido são o PT $(20,8 \%)$ e o PSB $(10,5 \%)$. Tomando a estratégia da capacidade como universo da análise, o peso do partido torna-se ainda mais significativo: em $45,5 \%$ das vezes em que o PT fez 
uso da mesma, a capacidade foi atribuída ao partido, enquanto para o PSB esse percentual foi de $24,2 \%$.

Com evidência, o PT destaca-se nesse tipo de estratégia, empenhando-se na transformação de um critério essencialmente personalista em um atributo coletivo. Na campanha presidencial, o partido enfatizou sua própria capacidade na gestão dos negócios públicos em $22,3 \%$ dos programas analisados, enquanto na campanha para governador do Rio Grande do Sul o percentual foi de 25,8. Apenas na campanha ao Senado, a ênfase na capacidade do partido foi mais restrita, tendo sido verificada em $12 \%$ dos casos analisados ${ }^{15}$.

De modo geral, mesmo quando a estratégia eleitoral de enfatizar a capacidade se referia ao candidato, o PT fez uso, fundamentalmente, do argumento da "competência política", ou seja, da capacidade do partido ou do candidato para conciliar divergências e arbitrar o conflito político. Desse modo, é possível dizer que o PT trata o argumento da competência sob um ponto de vista essencialmente coletivista, descaracterizando-o como um sintoma da personalização do jogo político e do declínio dos partidos no arbítrio da dinâmica democrática.

\section{CONSIDERAÇÕES FINAIS}

Este artigo teve como propósito analisar alguns dados relativos à propaganda política veiculada no HGPE 2002 à luz de algumas considerações teóricas relativas à crise dos partidos políticos nas democracias contemporâneas. Aventou-se a hipótese de que uma maior profissionalização das campanhas eleitorais e um crescimento dos eleitores pragmaticamente orientados não prenunciassem o declínio irreversível dos partidos políticos.

Como dito na primeira parte deste trabalho, a fim de se comprovar a hipótese da substituição dos partidos políticos pelos meios de comunicação na dinâmica eleitoral recente, seria preciso demonstrar, por um lado, a redução da identificação partidária pelos eleitores e, por outro, o declínio das estratégias comunicativas eleitorais que visam construir uma imagem coerente dos partidos junto ao eleitorado. Tanto os dados de identificação partidária no Brasil quanto a análise de algumas das estratégias de campanha dos partidos políticos fornecem subsídios para uma recusa da "hipótese da substituição". 
Os dados concernentes à identificação partidária no Brasil demonstraram um relativo fortalecimento do sistema partidário, apontando para o aumento no número de eleitores que se identificam com algum partido político. Além disso, o vigoroso crescimento na preferência partidária pelo PT aponta para o sucesso de suas estratégias de promoção da própria legenda.

Os dados referentes à campanha eleitoral de 2002 apontaram para o uso de estratégias coletivistas na comunicação televisiva com o eleitor, especialmente os que se referem ao PT. Quanto a este ponto, algumas considerações relativas à atuação individual dos partidos em seus programas televisivos devem ser feitas.

O partido que se comportou de forma mais individualista foi o PPS. As poucas referências partidárias em seus programas apareceram na campanha do candidato Ciro Gomes. No Rio Grande do Sul é possível dizer que esse é o partido dos "sem-partido", a ponto de os candidatos se referirem explicitamente às desvantagens do partidarismo para o interesse público. Em âmbito local, esse comportamento tem uma explicação: o PPS abriga hoje os principais antagonistas do PT no estado. O PT governa a capital do Rio Grande do Sul há dezesseis anos, tendo governado o estado entre 1998 e 2002. Como é possível notar pelos dados acima relacionados, o PT investe mais em sua própria imagem do que qualquer outro partido brasileiro. Sua legenda tornou-se a marca distintiva de seus candidatos e governos. A estratégia do antipartidarismo do PPS, especialmente no Rio Grande do Sul, reflete, sobretudo, sua oposição ao PT. Seria necessário verificar o comportamento do partido em outros estados a fim de comprovar a hipótese de seu individualismo extremado.

O PSDB, embora tenha sido predominantemente individualista em suas estratégias de campanha na televisão, apresentou alguns indícios de projeção de uma imagem coletiva, especialmente se considerado o contexto regional. Como o partido, em 2002, não indicou candidato a governador no RS, não se pode comparar as estratégias entre cargos executivos, em âmbito nacional e regional (RS). Mas, se cotejarmos, por exemplo, as campanhas para presidente da República (nacional) e para senador (regional), ambas as eleições de tipo majoritário, verificaremos uma diferença significativa no uso da legenda partidária: enquanto, na campanha para presidente, o uso da legenda partidária foi marginal (aparecendo em destaque em apenas 2,8\% dos 
programas analisados), na campanha para senador o uso da mesma foi constatado em $38 \%$ dos programas examinados. Sustento, portanto, a hipótese, a ser confirmada, de que esse partido apresenta uma identidade coletiva mais importante em âmbito regional (RS) do que nacional.

O PMDB apresentou um comportamento bastante semelhante ao do PSDB no que se refere à projeção de uma imagem coletiva, ressaltando-se um empenho relativamente maior do primeiro com relação ao segundo nesse sentido. Entretanto, como o PMDB não apresentou candidato à Presidência da República, possuo informações apenas sobre o seu comportamento no plano regional.

Apenas o PT e o PSB, este exclusivamente em termos regionais, utilizaram a estratégia coletivista em grau acentuado. São partidos que, na maioria das vezes, projetam sua sigla sobre as candidaturas individuais. O comportamento partidário do PT, especialmente por ser um dos grandes partidos nacionais, e seu sucesso eleitoral demonstram que não há uma demanda do eleitorado por um discurso essencialmente individualista, negando que o personalismo seja uma condição necessária ao jogo político eleitoral brasileiro.

Não somente a exemplaridade do caso do PT, como a utilização de estratégias coletivistas, mesmo que incipientes, por outros partidos na construção de suas imagens são indícios de que os partidos são capazes de reformular o contrato representativo com seus eleitores, adequando-se às novas demandas da contemporaneidade. Assim, constata-se que a ascensão de novas tecnologias de informação e comunicação não é, obrigatoriamente, responsável pelo declínio irreversível dos partidos na dinâmica política.

Finalmente, o surgimento de um eleitor mais informado e mais crítico quanto à condução governamental pelos atores políticos não preconiza uma maior personalização da política. As estratégias de estímulo ao voto retrospectivo e de ênfase na capacidade técnica ou política podem estar associadas à imagem de um partido e não necessariamente focadas no candidato. Mais uma vez o caso do PT é exemplar na projeção de sua própria legenda como fiadora da ação futura de seus candidatos.

Entretanto, os dados aqui analisados ainda não são suficientes para se fazer inferências seguras quanto ao rumo que os partidos políticos 
brasileiros tomarão daqui para a frente. É preciso resgatar um panorama evolutivo das campanhas eleitorais e analisar outras variáveis que reflitam as estratégias comunicativas que os partidos utilizaram ou ainda utilizam na construção de sua imagem.

(Recebido para publicação em novembro 2003)

(Versão definitiva em agosto de 2004)

\section{NOTAS}

1. Para mapear as linhas centrais do debate em torno da crise das democracias representativas, consultar: Cohen (1971), Habermas (1975), Brittan (1975), King (1975), Crozier et alii (1975), Hirschman (1982), Held (1987), Inglehart (1990) e Kaase (1990).

2. Sobre o declínio dos partidos nas democracias contemporâneas, ver: Bartolini e Mair (1990), Cain et alii (1987), Daalder e Mair (1983), Katz (1997), Lawson e Merkl (1988), Mair (1997), Samuels (1997) e Schmidt (1996).

3. Sobre a centralidade da televisão e personalismo político, ver, ainda, Popkin (1994), Mancini e Swanson (1996), Bourdieu (1997), Sartori (2001), Albuquerque e Dias (2002) e Albuquerque (2003).

4. Vale lembrar que a analogia entre política e mercado foi feita originalmente por Joseph Schumpeter (1961).

5. Para resultados eleitorais, ver encartes da Revista Opinião Pública. Para personalismo eleitoral no Brasil, ver Lavareda (1999) e Silveira (1998).

6. Para dados e análises acerca do comportamento político e eleitoral no início da redemocratização, especialmente no Rio Grande do Sul, ver Baquero (1984).

7. Ver análise a respeito da relação entre a queda do PDT e a ascensão do PT em Dias (2002).

8. Para uma aplicação da tese da mobilização cognitiva ao caso brasileiro, ver Baquero (1996).

9. Deve ficar claro que neste artigo pretendo, sobretudo, montar um quadro analítico e efetuar algumas avaliações preliminares a partir do HGPE 2002. Para uma investigação da evolução do discurso dos partidos, serão necessárias organização e análise do HGPE a partir de 1989.

10. O trabalho aqui efetuado não é exaustivo da pesquisa realizada. Para a dimensão intrapartidária, foram analisados os dados de apenas uma estratégia: o uso da legenda. Para a dimensão sistêmica, foram analisados os dados referentes a três tipos de estratégias: o voto prospectivo, o voto retrospectivo e a valorização da capacida- 


\section{Marcia Ribeiro Dias}

de técnica ou política. As conclusões deste artigo são, portanto, apenas preliminares, embora já seja possível identificar algumas tendências gerais.

11. Na análise dos programas, considerou-se como uso da legenda partidária o aparecimento da sigla do partido na tela; o uso da legenda da coligação, quando apareciam na tela as siglas de todos os partidos coligados na respectiva campanha; o símbolo da campanha correspondia ao nome de cada campanha acompanhada de algum símbolo específico.

12. Para mapear as linhas centrais do debate em torno da crise das democracias representativas, consultar: Cohen (1971), Habermas (1975), Brittan (1975), King (1975), Crozier et alii (1975), Hirschman (1982), Held (1987), Inglehart (1990) e Kaase (1990).

13. Sobre o declínio dos partidos nas democracias contemporâneas, ver: Bartolini e Mair (1990), Cain et alii (1987), Daalder e Mair (1983), Katz (1997), Lawson e Merkl (1988), Mair (1997), Samuels (1997) e Schmidt (1996).

14. Sobre a centralidade da televisão e personalismo político, ver, ainda, Popkin (1994), Mancini e Swanson (1996), Bourdieu (1997), Sartori (2001), Albuquerque e Dias (2002) e Albuquerque (2003).

15. Vale lembrar que a analogia entre política e mercado foi feita originalmente por Joseph Schumpeter (1961).

16. Para resultados eleitorais, ver encartes da Revista Opinião Pública. Para personalismo eleitoral no Brasil, ver Lavareda (1999) e Silveira (1998).

17. Para dados e análises acerca do comportamento político e eleitoral no início da redemocratização, especialmente no Rio Grande do Sul, ver Baquero (1984).

18. Ver análise a respeito da relação entre a queda do PDT e a ascensão do PT em Dias (2002).

19. Para uma aplicação da tese da mobilização cognitiva ao caso brasileiro, ver Baquero (1996).

20. Deve ficar claro que neste artigo pretendo, sobretudo, montar um quadro analítico e efetuar algumas avaliações preliminares a partir do HGPE 2002. Para uma investigação da evolução do discurso dos partidos, serão necessárias organização e análise do HGPE a partir de 1989.

21. O trabalho aqui efetuado não é exaustivo da pesquisa realizada. Para a dimensão intrapartidária, foram analisados os dados de apenas uma estratégia: o uso da legenda. Para a dimensão sistêmica, foram analisados os dados referentes a três tipos de estratégias: o voto prospectivo, o voto retrospectivo e a valorização da capacidade técnica ou política. As conclusões deste artigo são, portanto, apenas preliminares, embora já seja possível identificar algumas tendências gerais.

22. Na análise dos programas, considerou-se como uso da legenda partidária o aparecimento da sigla do partido na tela; o uso da legenda da coligação, quando apareciam na tela as siglas de todos os partidos coligados na respectiva campanha; o símbolo da campanha correspondia ao nome de cada campanha acompanhada de algum símbolo específico.

23. Percentual composto pela soma das variáveis "Campanha e/ou Coligação" e "Nenhuma". 
24. Importa ressaltar que o individualismo manifestado na campanha do PT-RS ao Senado se deveu à candidatura de Paulo Paim, que tem demonstrado em sua trajetória política bastante independência em relação ao partido.

25. Ver dados desagregados por cargo no Anexo 1 deste artigo.

26. Ver dados desagregados por cargo (PT) no Anexo 2 deste artigo.

\section{REFERÊNCIAS BIBLIOGRÁFICAS}

ALBUQUERQUE, A. de (2003), O Anfitrião Ausente: A Televisão nos Estudos sobre a Propaganda Política na Televisão. Trabalho apresentado no XII Encontro Anual da Compós, Recife, PE.

—_ e DIAS, M. R. (2002), “Propaganda Política e Construção da Imagem Partidária no Brasil”. Civitas - Revista de Ciências Sociais, vol. 2, no 2, pp. 309-326.

BAQUERO, M. (org.). (1984), Abertura Política e Comportamento Eleitoral. Porto Alegre, Editora da Universidade.

. (1996), A Tese da Mobilização Cognitiva e o Declínio dos Partidos. Trabalho apresentado no XX Encontro Anual da Associação Nacional de Pós-Graduação e Pesquisa em Ciências Sociais - Anpocs, Caxambu, MG.

BARTOLINI, S. e MAIR, P. (1990), Identity, Competition and Electoral Availability: The Stabilisation of European Electorates, 1885-1995. Cambridge, Cambridge University Press.

BOURDIEU, P. (1997), Sobre a Televisão. Rio de Janeiro, Jorge Zahar Editor.

BRITTAN, S. (1975), “The Economic Contradictions of Democracy". British Journal of Political Science, vol. 5, pp. 129-159.

CAIN, B., FEREJOHN, J. e FIORINA, M. (1987), The Personal Vote: Constituency Service and Electoral Independence. Cambridge, Ma., Harvard University Press.

COHEN, C. (1971), Democracy. New York, Free Press.

CROZIER, M., HUNTINGTON, S. P. e WATANUKI, J. (1975), The Crisis of Democracy: Report on the Governability of Democracies to the Trilateral Commission. New York, New York University Press.

DAALDER, H. e MAIR, P. (1983), Western European Party System: Continuity and Change. London, Sage Publications.

DALTON, R. J. (1984), “Cognitive Mobilization and Partisan Dealignment in Advanced Industrial Democracies". Journal of Politics, vol. 46, pp. 264-284.

e KUECKLER, M. (orgs.). (1990), Challenging the Political Order: New Social and Political Movements in Western Democracies. Cambridge, Polity Press. 


\section{Marcia Ribeiro Dias}

DIAS, M. R. (2002), “Hegemonia e Polarização: A Reconfiguração de Forças Políticas no Município de Porto Alegre (1988 a 2000)". Civitas - Revista de Ciências Sociais, vol. 2, no 1 , pp. 157-179.

GIBSON, R. e RÖMMELE, A. (2001), “Changing Campaing Communications: A Party-Centered Theory of Professionalized Campaigning". Harvard International Journal of Press Politics, vol. 6, no 4, pp. 31-43.

HABERMAS, J. (1975), Legitimation Crisis. Boston, Beacon Press.

HELD, D. (1987), Models of Democracy. Cambridge, Polity Press.

HIRSCHMAN, A. O. (1982), Shifting Involvements: Private Interest and Public Action. Princeton, NJ, Princeton University Press.

INGLEHART, R. (1990), "Values, Ideology and Cognitive Mobilization in New Social Movements", in R. J. Dalton e M. Kueckler (orgs.), Challenging the Political Order: New Social and Political Movements in Western Democracies. Cambridge, Polity Press.

KAASE, M. (1990), “Social Movements and Political Innovation”, in R. J. Dalton e M. Kueckler (orgs.), Challenging the Political Order: New Social and Political Movements in Western Democracies. Cambridge, Polity Press.

KATZ, R. (1997), Democracy and Elections. Oxford, Oxford University Press.

KING, A. (1975), “Overload: Problems of Governing in the 1970s”. Political Studies, vol. 23, pp. 284-296.

KLINGEMANN, H-D. e FUCKS, D. (1995), Citizens and the State. Oxford, Oxford University Press.

LAVAREDA, A. (1999), A Democracia nas Urnas. Rio de Janeiro, Revan.

LAWSON, K. e MERKL, P. (1988), When Parties Fail: Emerging Alternative Organizations. Princeton, Princeton University Press.

MAIR, P. (1997), Party System Change. Oxford, Oxford University Press.

MANCINI, P. e SWANSON, D. L. (1996), “Politics, Media, and Modern Democracy: Introduction", in D. L. Swanson e P. Mancini, Politics, Media and Modern Democracy: An International Study of Innovations in Electoral Campaigning and their Consequences. Westport/London, Praeger, pp. 1-26.

NEGRINE, R. M. e LILLEKER, D. G. (2002), “The Professionalization of Political Communication: Continuities and Change in Media Practices". European Journal of Political Communication, vol. 17, no 3, pp. 305-323.

NICOLAU, J. (org.). (1998), Dados Eleitorais do Brasil (1982-1996). Rio de Janeiro, Editora Revan/IUPERJ.

PLASSER, F. (2001), "Parties' Diminishing Relevance for Campaign Professionals". Harvard International Journal of Press Politics, vol. 6, nº 4, pp. 44-59.

POPKIN, S. (1994), The Reasoning Voter: Communication and Persuasion in Presidential Campaigns (2 ${ }^{a}$ ed.). Chicago, The University of Chicago Press.

RÖMMELE, A. (2003), "Political Parties, Party Communication and New Information and Communication Technologies". Party Politics, vol. 9, nº 1, pp. 7-20. 
Projeção da Imagem Partidária nas Estratégias de Campanha na Televisão...

SAMUELS, D. (1997), “Determinantes do Voto Partidário em Sistemas Eleitorais Centrados no Candidato: Evidências sobre o Brasil". Dados, vol. 40, no 3, pp. 493-533.

SARTORI, G. (2001), Homo Videns: Televisão e Pós-Pensamento. Bauru, SP, Edusc.

SCHMIDT, M. (1996), “When Parties Matter: A Review of the Possibilities and Limits of Partisan Influence on Public Policy". European Journal of Political Research, vol. 30, no 2, pp. 155-183.

SCHUMPETER, J. A. (1961), Capitalismo, Socialismo e Democracia. Rio de Janeiro, Fundo de Cultura.

SILVEIRA, F. E. (1998), A Decisão do Voto no Brasil. Porto Alegre, EDIPUCRS. 


\section{GLOSSÁRIO}

Arena - Aliança Renovadora Nacional

MDB - Movimento Democrático Brasileiro

PDS - Partido Democrático Social

PDT - Partido Democrático Trabalhista

PFL - Partido da Frente Liberal

PMDB - Partido do Movimento Democrático Brasileiro

PP - Partido Progressista

PPB - Partido Progressista Brasileiro

PPR - Partido Progressista Reformador

PPS - Partido Popular Socialista

PRN - Partido da Reconstrução Nacional

PSB - Partido Socialista Brasileiro

PSDB - Partido da Social Democracia Brasileira

PT - Partido dos Trabalhadores

PTB - Partido Trabalhista Brasileiro 
Projeção da Imagem Partidária nas Estratégias de Campanha na Televisão...

\section{ANEXO 1}

Referência a Realizações

\begin{tabular}{|c|c|c|c|c|c|c|}
\hline Partido & Cargo & & \begin{tabular}{|c} 
Parti- \\
do
\end{tabular} & $\begin{array}{c}\text { Candi- } \\
\text { dato }\end{array}$ & $\begin{array}{c}\text { Ne- } \\
\text { nhum }\end{array}$ & Total \\
\hline \multirow[t]{4}{*}{ PT } & Presidente & $\begin{array}{c}\text { Count } \\
\% \text { Cargo } \\
\text { \% Referência a Realizações }\end{array}$ & $\begin{array}{c}6 \\
16,7 \% \\
35,3 \% \\
\end{array}$ & & $\begin{array}{c}30 \\
83,3 \% \\
44,8 \% \\
\end{array}$ & $\begin{array}{c}36 \\
100,0 \% \\
37,5 \% \\
\end{array}$ \\
\hline & Governador & $\begin{array}{c}\text { Count } \\
\% \text { Cargo } \\
\text { \% Referência a Realizações }\end{array}$ & $\begin{array}{c}10 \\
28,6 \% \\
58,8 \% \\
\end{array}$ & & $\begin{array}{c}25 \\
71,4 \% \\
37,3 \% \\
\end{array}$ & $\begin{array}{c}35 \\
100,0 \% \\
36,5 \% \\
\end{array}$ \\
\hline & Senador & $\begin{array}{c}\text { Count } \\
\% \text { Cargo } \\
\% \text { Referência a Realizações }\end{array}$ & $\begin{array}{c}1 \\
4,0 \% \\
5,9 \% \\
\end{array}$ & $\begin{array}{c}12 \\
48,0 \% \\
100,0 \% \\
\end{array}$ & $\begin{array}{c}12 \\
48,0 \% \\
17,9 \% \\
\end{array}$ & $\begin{array}{c}25 \\
100,0 \% \\
26,0 \%\end{array}$ \\
\hline & Total & $\begin{array}{c}\text { Count } \\
\% \text { Cargo } \\
\% \text { Referência a Realizações }\end{array}$ & $\begin{array}{c}17 \\
17,7 \% \\
100,0 \% \\
\end{array}$ & $\begin{array}{c}12 \\
12,5 \% \\
100,0 \% \\
\end{array}$ & $\begin{array}{c}67 \\
69,8 \% \\
100,0 \% \\
\end{array}$ & $\begin{array}{c}96 \\
100,0 \% \\
100,0 \%\end{array}$ \\
\hline \multirow[t]{4}{*}{ PSB } & Presidente & $\begin{array}{c}\text { Count } \\
\% \text { Cargo } \\
\text { \% Referência a Realizações }\end{array}$ & & $\begin{array}{c}17 \\
60,7 \% \\
100,0 \% \\
\end{array}$ & $\begin{array}{c}11 \\
39,3 \% \\
21,2 \% \\
\end{array}$ & $\begin{array}{c}28 \\
100,0 \% \\
36,8 \%\end{array}$ \\
\hline & Governador & $\begin{array}{c}\text { Count } \\
\% \text { Cargo } \\
\text { \% Referência a Realizações }\end{array}$ & $\begin{array}{c}6 \\
26,1 \% \\
85,7 \% \\
\end{array}$ & & $\begin{array}{c}17 \\
73,9 \% \\
32,7 \% \\
\end{array}$ & $\begin{array}{c}23 \\
100,0 \% \\
30,3 \%\end{array}$ \\
\hline & Senador & $\begin{array}{c}\text { Count } \\
\% \text { Cargo } \\
\% \text { Referência a Realizações }\end{array}$ & \begin{tabular}{|c|}
1 \\
$4,0 \%$ \\
$14,3 \%$ \\
\end{tabular} & & $\begin{array}{c}24 \\
96,0 \% \\
46,2 \% \\
\end{array}$ & $\begin{array}{c}25 \\
100,0 \% \\
32,9 \% \\
\end{array}$ \\
\hline & Total & $\begin{array}{c}\text { Count } \\
\% \text { Cargo } \\
\% \text { Referência a Realizações }\end{array}$ & $\begin{array}{c}7 \\
9,2 \% \\
100,0 \%\end{array}$ & $\begin{array}{c}17 \\
22,4 \% \\
100,0 \%\end{array}$ & $\begin{array}{c}52 \\
68,4 \% \\
100,0 \%\end{array}$ & $\begin{array}{c}76 \\
100,0 \% \\
100,0 \%\end{array}$ \\
\hline
\end{tabular}




\begin{tabular}{|c|c|c|c|c|c|c|}
\hline \multicolumn{7}{|c|}{$\begin{array}{c}\text { Partido dos Trabalhadores - PT } \\
\text { Valorização da Competência } \\
\text { Técnica ou Política }\end{array}$} \\
\hline Cargo & & Partido & Candidato & Ambos & Nenhum & Total \\
\hline Presidente & $\begin{array}{c}\text { Count } \\
\text { \% Cargo } \\
\text { \% Capacidade }\end{array}$ & $\begin{array}{c}2 \\
5,6 \% \\
15,4 \% \\
\end{array}$ & $\begin{array}{c}11 \\
30,6 \% \\
45,8 \% \\
\end{array}$ & $\begin{array}{c}6 \\
16,7 \% \\
85,7 \% \\
\end{array}$ & $\begin{array}{c}17 \\
47,2 \% \\
32,7 \% \\
\end{array}$ & $\begin{array}{c}36 \\
100,0 \% \\
37,5 \% \\
\end{array}$ \\
\hline Governador & $\begin{array}{c}\text { Count } \\
\text { \% Cargo } \\
\text { \% Capacidade }\end{array}$ & $\begin{array}{c}8 \\
22,9 \% \\
61,5 \% \\
\end{array}$ & $\begin{array}{c}5 \\
14,3 \% \\
20,8 \% \\
\end{array}$ & $\begin{array}{c}1 \\
2,9 \% \\
14,3 \% \\
\end{array}$ & $\begin{array}{c}21 \\
60,0 \% \\
40,4 \% \\
\end{array}$ & $\begin{array}{c}35 \\
100,0 \% \\
36,5 \% \\
\end{array}$ \\
\hline Senador & $\begin{array}{c}\text { Count } \\
\text { \% Cargo } \\
\text { \% Capacidade }\end{array}$ & $\begin{array}{c}3 \\
12,0 \% \\
23,1 \% \\
\end{array}$ & $\begin{array}{c}8 \\
32,0 \% \\
33,3 \% \\
\end{array}$ & & $\begin{array}{c}14 \\
56,0 \% \\
26,9 \% \\
\end{array}$ & $\begin{array}{c}25 \\
100,0 \% \\
26,0 \% \\
\end{array}$ \\
\hline Total & $\begin{array}{c}\text { Count } \\
\text { \% Cargo } \\
\text { \% Capacidade }\end{array}$ & $\begin{array}{c}13 \\
13,5 \% \\
100,0 \%\end{array}$ & $\begin{array}{c}24 \\
25,0 \% \\
100,0 \%\end{array}$ & $\begin{array}{c}7 \\
7,3 \% \\
100,0 \%\end{array}$ & $\begin{array}{c}52 \\
54,2 \% \\
100,0 \%\end{array}$ & $\begin{array}{c}96 \\
100,0 \% \\
100,0 \%\end{array}$ \\
\hline
\end{tabular}




\begin{abstract}
Projection of the Party Image in Television Campaign Strategies: An Analysis of Free Campaign Advertising time on Brazilian Television in 2002
\end{abstract}

The objective of this article is to challenge the argument that political parties are replaced by the mass communications media in contemporary electoral dynamics. The article seeks to demonstrate that the causes for the political parties' decline are independent of the professionalization of election campaigns. The latter results exclusively from technological modernization, a process to which political parties may adjust more or less efficiently. The article analyzes the construction of the party image during the free TV campaign advertising time in Brazil in 2002 in order to demonstrate the use of collectivist strategies by the parties, highlighting a possible strengthening of their role through the TV campaign advertising.

Key words: party image and identification; campaign professionalism; free TV campaign advertising

\title{
RÉSUMÉ
}

Influence de l'Image des Partis dans les Stratégies des Campagnes Électorales à la Télévision: Une Analyse du HGPE 2002 (Émission Gratuite de Propagande Électorale)

Dans cet article, on remet en question l'argument selon lequel les partis politiques seraient, dans la dynamique électorale contemporaine, remplacés par les moyens de communication. On cherche à montrer que les causes de l'affaiblissement des partis politiques dans l'exercice de leurs fonctions traditionnelles sont distinctes de la mise en œuvre des campagnes électorales. Cette mise en œuvre n'est que le résultat de la modernisation technologique, à laquelle les partis peuvent s'adapter plus ou moins efficacement. On analyse ici la construction de l'image des partis dans le HGPE 2002 afin de montrer qu'ils utilisent des stratégies collectives, ce qui semble renforcer leur rôle dans les campagnes qu'ils présentent à la télévision.

Mots-clé: image et identification aux partis; mise en œuvre des campagnes électorales, HGPE 2002 